\title{
UNDERDOGS IN DIALOGUE
}

Age of Entanglement: German and Indian Intellectuals across Empire. By Kris Manjapra. Cambridge, MA, and London: Harvard University Press, 2014. Pp. 442.

\section{ABSTRACT}

The study of cultural interactions between Asia and Europe in modern times has moved beyond a mere description of mutual "images" and a ritualized assertion of fundamental incompatibility in the dichotomous tradition going back to the critique of Orientalism. Using "entanglement" as his guiding concept, the author unfolds a rich panorama of Indian and Germanic (including Austrian and Swiss) intellectuals in personal contact and distant dialogue from the 1880 s to 1945 . Their shared framework of meaning was the resistance to "empire." The book ambitiously advances a broader vision of global intellectual history. This raises a number of theoretical issues requiring further debate.

Keywords: global intellectual history, entanglement, Orientalism, anti-colonialism, India, Germany

At a time when the embattled humanities are hard-pressed to prove their usefulness, the modest historical monograph of old will no longer do. Diligent research and the careful crafting of arguments are expected to support larger vistas of interpretation. Empirical investigations call for being wrapped up in theory; a given special topic bears the burden of novel visions of the past.

Kris Manjapra's book, based on his $\mathrm{PhD}$ thesis, is a representative example of such a monograph with a mission. Deploying all the tools of the historical craft, it tells a story: the story of the relations between Indian and German intellectuals during the period from about 1880 to 1945 . At the same time, it advances a number of major theoretical claims that frame the analysis from the very outset; they also emerge, in a somewhat circular fashion, as the principal conclusions of the book. These claims relate to the concept of "entanglement," to periodization, to the connection between empire and discursive "hegemony," to the notions of Enlightenment and post-Enlightenment, to "enchantment" through science, and to a recasting of "Orientalism."

It seems sensible to discuss the two aspects of this book separately, that is, to start with the story and then to move on to its wider implications. Even so, we must begin with a few remarks on the notion that already dominates the book's title. "Entanglement" is undoubtedly the key concept of the entire work, used from the very beginning to frame questions and to organize the material. But what does it mean? The term arose from the early programs of l'histoire croisée, and it was originally suggested in order to refine simple ideas of "cultural 
transfer." It added a note of stable complexity to a mere tracing of sporadic and linear "influences" and "impacts," and it usually referred to a particularly intense and long-lasting relationship between entities that preserve their own identities. Entanglement characteristically takes place not between individuals, but between whole groups or even societies. There is a broad range of possibilities for such intertwining. Societies become systematically entangled, for example, in border zones where bilingualism prevails and jurisdictions, at least in premodern times, often overlap. Entanglement assumes a particular intensity whenever one society is superimposed upon another as in cases of military conquest, occupation, and, of course, colonialism. Thus, France and Germany have never been more intensely "entangled" than during the years 1940 to 1944, an example that should dispel any confidence in the basically peaceful and harmonious qualities of entanglement.

Entanglement may be a more or less stable or even permanent condition, but it can also express itself in the dynamics of social change and cultural hybridization, frequently ending up in the extremes of amalgamation or dissolution. Immigrant diasporas, for instance, always interact with their host environment, yet some of them resist assimilation while others ultimately melt away into a larger social universe. All these aspects of the theme are easily accommodated within a concept of great elasticity. "Entanglement" is one of those magic words that conjures up profundity while lacking the sharp contours of a well-defined analytical category; authors need to tell their readers what they mean when they use it.

Manjapra does not shirk this responsibility. He gives a remarkable twist to a concept that tends to suffer from excessive vagueness. Entanglements, he posits, "occur when groups, alien from each other in many other ways, begin to need each other . .." (6). "In other words," he continues, "entanglements are always political-they have more to do with the realm of necessity and power than with the realm of freedom" (6). Refusing to revel in "the charms of cross-cultural encounter" and also eschewing the pieties of a ritualized critique of colonial domination, Manjapra resurrects a category that cultural history has largely allowed to fall into oblivion - the category of "interest." "What do different groups, some stronger, some weaker, get out of their political relations together?" (6). Strategically placed at the center of the Introduction, this seems to be the overarching question of the book. It claims to be a study of the "realpolitik" of "transnational intellectual history" or, put differently, a contribution to the history of "intellectual politics" (7).

As welcome as such tough-minded precision sounds at a time of fashionable fuzziness, and especially in the aftermath of rampant Saidism with its gospel of an all-pervading discursive conditioning of actors and speakers, the reader is apprehensive as to how a political perspective in terms of interests, tactics, and alliances will be sustained in a long-term study of relations between Indian and German intellectuals. That Manjapra allows the word "dialogue" to slip in at this early stage in the book (7) indicates a possible softening of his strictly instrumentalist approach. A dialogue in the normal sense of the word presupposes a kind a fundamental empathy shared by the partners in conversation. It relegates into the background the intention to manipulate the interlocutor and to use her or him to 
promote one's own selfish ends. In this, a dialogue is distinguished from business talk or negotiation. And indeed, the book, much to its advantage, does not stick to its initial, hard-nosed line. The more we read on, the less prominent the aspect of "realpolitik" becomes, and it is no surprise that on the final pages the concept of "entanglement" is eclipsed by the invocation of "dialogic action in the pursuit of new intellectual authority," and of "transnational dialogue" (273). Gone is the flamboyant ambition to recast the concept of "entanglement," and yet the gain is considerable: a subtle and richly nuanced description of how, when, and why Indians and Germans discovered, explored, and developed common interests.

In the first part of the book, chapters 1 to 4 delineate "stages of entanglement" or, in slightly more sober parlance, periods of reception, recognition, and interaction. Manjapra begins conventionally with the by now familiar topic of Germans in the service of the British Empire. From Forster père et fils who famously accompanied Captain Cook on his second circumnavigation, to experts on forestry or cooperative banking who worked for the High Victorian Raj, the beneficiaries of a good German education with their scholarly competence and technical skills became indispensable for running British ventures of exploration and colonialism. Manjapra draws our attention to a number of little-known Indologists - Georg Bühler among them-who made a considerable impact in India. But generally he makes a bit too much of an alleged German inferiority complex vis-à-vis "British cultural supremacy" (39). When, discussing the formidable and in no way submissive Forsters, he mocks a "German mimicry of the style of the British ruling classes" (19), he is clearly overstating his case. Marveling at the expatriate professional activities of Germans said to grieve for their "own" nonexisting empire misses the point that for the early modern European empires - and well into the nineteenth century - cosmopolitan management was the rule rather than the exception. The Spanish Empire was never run by Spaniards alone, and the Dutch East India Company (VOC) was the biggest transnational employer of its age.

Manjapra provides insufficient evidence for his claim that German scholars working in India, or as armchair indologists in Europe, on Indic topics considered their role as "marginal" (20) and compensated for their remoteness from the sources of global power with excessive scholarly fervor. One should not underestimate the supreme self-confidence of academic mandarins like Franz Bopp in Berlin or Friedrich Max Müller in Oxford, who had no reason to resent any possible "backwardness" of the German Geisteswissenschaften. Evidence and lucidity of argument are also missing when Manjapra asserts "the overwhelming importance of German philosophies for the consolidation of British rule in India" (22). For "German philosophies," given the period in question, one has to read "Hegelianism," and it would require a greater effort than Manjapra's offhand conjecture to see the famous English and Scottish utilitarians displaced as the guardian angels of British colonialism by German disciples of the great philosopher of the spirit.

Chapter 2 finds Manjapra on firmer ground. He has now reached his chosen threshold of 1880 and splendidly introduces some of the major characters of his Indian cast, above all the herald of a new Indian internationalism transcending the 
framework of the British Empire, Aurobindo Ghosh, alongside the cosmopolitan nationalist and great academic institution-builder, Asutosh Mukherjee. These early activists of Indian self-rule saw Germany, Japan, and the United States as "the major models for a muscular nationalism that Indians themselves had to cultivate" (46). Their admiration for German science was not only inspired by the intrinsic qualities of the Humboldtian university, but was also suffused with the impression that advanced forms of organized scholarship contributed mightily to Germany's ever-growing strength as a nation. As one eminent Bengali educationist pertinently remarked: "Germany's national struggle was an educational one." Sending as many Indian students as possible to the Germanic lands-Vienna and Zurich were easily incorporated into Asian geographical visions of the German-speaking intellectual sphere - to obtain degrees in the natural sciences and engineering became an urgent priority. The much-maligned British Raj, it has to be added, seemed to have done very little to impede this self-strengthening quest for Continental knowledge. It may have had its own reasons for a neglect of "realpolitik," which would never have occurred, for instance, in the culturally mercantilist French colonial empire.

The following two sections of the unfolding story address the time-honored topic of mutual perceptions, of German "orientalism" and its mirror imageIndian "occidentalism." The first of these aspects is anything but a white spot on the map of historical research. On Arthur Schopenhauer's and Hermann Hesse's Indian infatuation, and also on theosophy - the movement that "opened up pathways for everyone to become sages" (64) - almost nothing seems to have been left unsaid. Manjapra makes his distinctive mark by probing the depths of German Aryanism. His most interesting contribution is to trace the continuities and ruptures between nineteenth-century Indic philology and mythography, on the one hand, and the new "Aryan studies" of the post-World War I period, on the other. The most potent post-Versailles motive, and one with a broader popular appeal, was the consoling belief that the Germans had deeper roots in a global past than could be compromised or eradicated by the trauma of 1918: "To think of oneself as an Aryan after World War I was to still be at home in the world even after a world-historical war defeat" (80). Without elaborating on the point, Manjapra hints at the paradox of exoticizing displacement. Claiming ancestry in the deep Asiatic past may have consoled the defeated and mentally slighted Germans but it also meant a further step toward "provincializing Europe" - a thought that had already occurred to Oswald Spengler during the final stages of the war.

The chapter on corresponding "Indian visions of a German home" begins ominously with some embroidered prose on the "choreography" of transnational encounters and the Indians' urge "to resituate their place in the world." Fortunately, the author then changes gear and provides a most informative and richly detailed study of the Indian communities in German cities, above all in Berlin, during the 1920s. The Indians were mostly well integrated into German society, and a surprising number of the male members of the community were married to German women. At the same time, it was still possible for an entrepreneur from the Hagenbeck dynasty of animal traders and circus owners to put "native" South Asians on public display. For the time being, German foreign policy remained 
unresponsive to the anti-British aspirations of Indian expatriates, but then the hopes of some-how many?-among the community regarding Nazi support for India's struggle for liberation rapidly evaporated, a story more extensively told elsewhere. Manjapra needs this episode to support his overall argument of a long-term Indo-German alliance against Britain. However, he has to navigate these treacherous waters cautiously. The mainstream of Indian nationalism, of course, never preferred Hitler and the Emperor of Japan to Churchill and his viceroys, and any "realpolitik" foundered on the obvious nature of a radically racist regime that never recognized South Asians as its "Aryan" brethren. Manjapra mentions something about "a great deal of historical momentum behind these alliances" (108) concluded by Subhas Chandra Bose and his friends. But this cannot disguise the fact that the "internationalist" sympathy between the Indian and German adversaries of the British Empire was wrecked as a result of the moral choices imposed by a regime whose own quest for world power could not be more remote from any cosmopolitan anti-imperialism.

The main part of the book consists of six long chapters that analyze different "fields of encounter": the physical sciences, international economics, programs of Marxist world revolution, geopolitics, psychoanalysis, and the East-West bridging of art worlds. It is in these central chapters, impeccably researched and generally careful and nuanced in their interpretive conclusions, that we find the book's most valuable contributions. The important work of Indian physicists, one of whom, C. V. Raman from South India, won the 1930 Nobel Prize for his discoveries in the field of optics, is placed within an Indian context where Germany with its highly advanced work both in theoretical and experimental physics served as an almost inevitable model for the establishment of Indian academic institutions. Leading German scientists such as Albert Einstein, Walther Nernst, and Max Born were eager to cultivate relationships with their South Asian colleagues and disciples. Indeed, fleeing Nazi persecution, Born even worked in Raman's Bangalore for six months - though the experience was not a happy one as he was caught up in an "intensive intranationalist struggle" (139).

Manjapra claims that Indians and Germans characteristically found common ground in "counterscientific fields" that represented progressive "transformations of scientific positivism" (111), while British, and perhaps Anglo-Saxon, science was presumably stuck in a mindless, nineteenth-century accumulation of facts. This severely underrates the universalism of the natural sciences to which the Indian physicists gladly contributed. Ever since the turn of the century, advanced physics in any country was "post-positivist," and when the Nazis finally launched their own kind of racially based "counterscience" - the "Deutsche Physik" propagated by Nobel Prize-winner Philipp Lenard-it was viewed as a bizarre joke without the slightest international resonance. If any Indian scientists seized this opportunity for a strategic alliance against "hegemonic" science of the Einsteinian type, Manjapra does not mention them. Lenard and his fellow advocates of a Germanic revolt against an alleged Jewish supremacy in theoretical physics are absent from the book.

Psychoanalysis and geopolitics are markedly stronger candidates for the status of "counterscience," and in these cases Manjapra's thesis of Indo-German antihegemonism works quite well. Psychoanalysis qualifies as a decidedly "post- 
Enlightenment" enterprise, although, it has to be acknowledged, by no means an anti-modernist one. Ironically, in this particular example the hegemonic "other" does not assume the shape of some kind of British positivist specter but is incarnated in Wilhelm Wundt's Leipzig school of experimental psychology. Whether the center-periphery model is actually appropriate for understanding the development of psychoanalysis should offer further food for thought. Was "the Austrian Freud" in a similar way a man "on the margins" as his Indian followers? After all, fin-de-siècle Vienna was a world center of artistic, philosophical, and also scientific innovation; it was neither peripheral within the Habsburg Empire nor in relation to Cambridge, Chicago, Leipzig, or Berlin, and Sigmund Freud's fame increasingly spread across the globe, unchecked by the resistance his teachings encountered on the part of mainstream psychology and psychiatry. The more convincing argument made in Manjapra's discussion of psychoanalysis is that Freud's follower Girindrasekhar Bose used the intellectual resources offered by Freud to fortify "Indian selfhood" and to "place it at the top and center of the world order" (217). Freud, here gently and predictably rebuked for clinging to "a belief in the superiority of European, male, and high-middle class social values" (218), was stood on his anti-Eurocentric feet by Indian students of the human psyche who blended "Germanic psychoanalytic science with high-caste Hindu modes of portraying the mind" (227).

If, apart from the rampant occultism of the 1920s, there was a "counterscience" bordering on the dubious, it was certainly German Geopolitik (in this spelling to be distinguished from other kinds of geopolitics). It also had political consequences diametrically opposed to those of psychoanalysis. Sigmund Freud was driven into British exile, and his followers were banned from teaching positions, persecuted all over German-occupied Europe, and scattered across the planet. By way of contrast, Geopolitik, a brand of political geography that was given a modicum of coherence in the numerous works of the Bavarian general Karl Haushofer, fed directly into Nazi revisionism of Versailles and later into Hitler's pursuit of Lebensraum in the East. Haushofer's conservative brand of geographical determinism was bound to clash, sooner or later, with the racial determinism of more radical Nazi enthusiasts, and his influence on policy-making was to dwindle rapidly. But the thrust of the geopolitical discourse, already in the writings of its precursors before 1914, had always been explicitly directed against AngloAmerican "world domination." Haushofer, a keen student of Japan and apologist of Japanese imperialism, professed sympathy for the "enslaved peoples of the East" that effortlessly translated into the advice to join their liberation struggles with German and Japanese attempts at overturning the postwar international order. Little wonder that Asian nationalists listened carefully.

However, in chapter 8, titled "Geocultural Wholes," Manjapra is stronger on German identifications with India than on views from the East. Haushofer himself, we are told, underwent a process of "self-Orientalization" (202), even using a terminology of "subalternity" that should give the later Marxist proponents of the concept uneasy feelings about this embarrassing right-wing companionship. Manjapra, too, seems to have mixed feelings about Anglophobe anti-imperialism: "As much as German nationalists wanted to be colonizers again, they also saw 
themselves as the colonized" (204). Indeed, but when they turned into colonizers again, as they did in Eastern Europe from 1939, they quickly dispelled any doubt that they would have also been terrible masters of the extra-European world. The Indian geopoliticians and advocates of "geocultural holism," Benoy Kumar Sarkar foremost among them, found little difficulty in switching from anti-British "internationalism" to visions of Hindu or Greater Bengali ethnic supremacy; Manjapra even speaks of "Sarkar's fascism" (209). Paradoxically, practical entanglement between Indian and German activists and texts gave rise to sinister ideologies of disentanglement in the name of cultural sameness and racial purity.

The shining heroes of entanglement are not crowded into any particular chapter; one meets them throughout the book. Rabindranath Tagore, who, as a poet, prose writer, painter, and political and cultural critic, acquired a prominent group of German admirers, easily heads the list. But there are also intriguing portraits of lesser-known figures. Among them is the Social Democrat and trade union functionary Franz Josef Furtwängler, who turned himself into the leading South Asianist on the moderate German left, a man whose own India was that of the laboring poor rather than that of brahmanic sages. The most subtle and sympathetic personal sketch in the book, however, is devoted to the indefatigable Stella Kramrisch, whose zealous building of bridges between Western (not just German) and Indian art and artists lasted from her Viennese doctorate in 1919 to her final exhibition in 1983. Kramrisch "contributed to the aesthetic rebellion in India" (238), but she was essentially a genuine cultural broker working in both directions rather than an anti-colonial partisan. Considering the broader context, Manjapra nicely chisels out the paradox that the anti-fascist scholars of the Warburg Institute who had found refuge in London continued to uphold the Western canon, whereas their pro-Nazi antagonist Josef Strzygowski in Vienna was far less "Eurocentric" and employed visions of an anti-Western commonality of "Eastern" art "in order to boost German Europe's geopolitical status, as well as to support claims about a purified Aryan cultural world rooted in the ancient East" (254). Manjapra speaks about Kramrisch with a warmth that is rare in his comments on other German friends of India; one is almost reminded of Edward Said's theoretically unguarded eulogy of Louis Massignon in his famous Orientalism of 1978. Facing such a degree of quiet professionalism and deeply felt dedication, Manjapra for once abandons the strong theses that he otherwise sells quite hard to his readers.

Some of those theses, elaborated with great rhetorical flourish, shroud the book in an aura of excitement and originality. They will certainly provoke controversy since their scope of ambition frequently transgresses the evidence provided in the individual chapters.

First, Manjapra extends the Enlightenment through the nineteenth century and right up to 1880 , or even later: "the age of enlightenment came to its final [!] end at the conclusion of the nineteenth century" (190). He thus asserts a "very long" early modern period in the history of ideas - "stretching in earnest from the seventeenth to the nineteenth centuries" (8). Since this is at variance with common usage and, more important, also with the most careful reconstructions of the historical Enlightenment as recently as in the work of J. G. A. Pocock or 
Jonathan Israel, a longer and more precise explanation would have been helpful. Even invoking the authority of Michel Foucault is not really convincing since Foucault gave no indication that one of his famous coupures between epistemic formations might have occurred after the third quarter of the nineteenth century. Manjapra seems to believe that the Enlightenment was a "positivistic" discourse of universalism proclaiming "rational universal laws" (8), that this discourse manifested itself "hegemonically" in all forms of cognitive activity, including the entire range of the sciences from the hermeneutical disciplines to theoretical physics, and that this kind of dominant knowledge "was most forcefully disseminated at that time by British institutions in the world" (9) and thereby provided the ideological underpinnings of the British Empire, which is seen as the embodiment of some evil and sterile universalism.

Manjapra refrains from a closer engagement with even the most important of his "Enlightenment" thinkers, but at least he mentions the names of three witnesses, only one of them British (10): John Stuart Mill, Auguste Comte, and the anthropologist, pathologist, and social critic Rudolf Virchow, the latter a rather unlikely choice for an originator of "rational universal laws." After about 1880, "knowledge production," presumably on a worldwide scale, became particularistic, "comparativist, expressivist, and relativistic" (10). It would have been interesting to learn more about Manjapra's views on Nietzsche (and his influence), Bergson, Durkheim, Husserl, Russell, neo-Kantianism, or the "crisis of Historismus" around 1900, to name but a few Eurocentric authorities and trends. Without this kind of critical reasoning, accepting Manjapra's new periodization of global intellectual history remains a matter of faith.

Second, in some form of impersonation of Marxist Widerspiegelungstheorie (which regards ideology as a superstructural reflection of the "material basis") Manjapra perceives a correspondence between prevailing forms of thought and the general political situation. When the state-system falls apart, so does the prevalent mode of thought. The emergence of particularistic "post-Enlightenment" thinking goes hand in hand with "the growth of national consciousness" (11). He assumes a peacefully integrated and harmonious Europe that, under uncontested British leadership, was busy imposing itself on the rest of the world throughout a "short" nineteenth century. The "Concert of Europe" broke apart after 1880 amid the rivalries of high imperialism. This seems to be a fairly extravagant reading of the political history of nineteenth-century Europe. Certainly, the continent was mainly peaceful from 1815 to 1853 , but it was definitely not under British leadership. After the Crimean War, the Royal Navy continued to dominate the high seas while British foreign policy was powerless to influence statesmen like Bismarck or Napoleon III. British leadership of a tightly knit pre-1880 Europe is a myth, and even after 1880, "fragmentation" among the great powers was temporarily shelved whenever they felt shared interests were at stake-witness the joint military action against China in 1900.

The same is true, third, as far as British "discursive" preeminence is concerned. Manjapra has successfully steered discussions of German-Indian relations away from the foggy realm of "elective affinities" and the meeting of "kindred" souls and spirits. He has de-Orientalized and de-exoticized the topic. His persuasive 
solution is that Indians and Germans shared a comparable historical position: that of being on the periphery in relation to the central British Empire. But comparable to what degree, and where do the analogies end? Speaking, or so it seems, of both periods before and after the great divide of 1880, Manjapra offers this as one of his principal axioms: "German and Indian intellectuals and their institutions of knowledge chafed under the global hegemony of Anglo-Saxon power" (8). Gottschied, Lessing, or even Herder in the eighteenth century may have "chafed" under, and suffered from, French cultural preponderance as it was upheld by a long-reigning Prussian king. But did Alexander von Humboldt or Justus Liebig have anything but a relationship of respectful equality with their British contemporaries? Where was the British philosopher or historian whose arrogance would have offended the incomparable Hegel and the masterful Ranke? Did Wilhelm Dilthey or Max Weber, Robert Koch or Max Planck really feel hegemonically constrained by their colleagues from Oxford, Cambridge, or Edinburgh, or even by the power of the British Empire as such? It seems doubtful. And Manjapra likewise over-stretches a well-taken point when he assumes a kind of "empire envy" on the part of the Germans. The fact of lacking an overseas empire did not mean that a great number of people in Germany coveted one. When Bismarck acquired the German colonies in Africa in 1884-1885, he was not driven by a desire to catch up with the British, and the modest public support he enjoyed for his achievement did not harp on the theme of German backwardness. The longing for a German "place in the sun"-the phrase was coined as late as 1897-is quintessentially Wilhelminian. In contrast to the Indians, the Germans, let alone the Swiss and the Habsburg Austrians, were neither colonial subjects of the British nor victims of British, or even jointly Anglo-American, political or cultural oppressiveness. Only from 1918 onwards did the Versailles syndrome create a sense of wounded pride and collective degradation. But by that time, "Anglocentrist structures and symbols of world order" (290) had been severely attenuated, and a more diffuse "West," composed of the former Allied powers and led by French "revanchism," took the role of prime national enemy in the imagination of the German right, while the left resented a global capitalism directed from the United States. At the same time, the Indian freedom movement became locked in close combat with the British colonial power. In this combat, German foreign policy could do nothing to help the struggling Indians, and German intellectuals were unable to offer more than their solidarity and a couple of visions for a postcolonial future.

Manjapra ends on a melancholy note of disentanglement. Already in earlier chapters, he had lamented the fragility of the Indo-German meeting of minds, for instance in the case of "radical globalist visions" of the world economy (170). The relations frayed, and the dialogues fizzled out during the Second World War-ironically at the very time when Germany mounted its biggest ever challenge to the West, and the Indians prepared for independence without any German political or intellectual assistance. In a moment of despair, the author appears close to canceling the main message of his entire book (unless the following assertion is of the utmost triviality): "India and Germany had never been on parallel paths, politically or socially speaking. The discrepancies between their 
historical trajectories are just as important as the entanglements" (277). After 1945, he tells us, Indian and German intellectuals parted ways; if anything survived of "Indic Orientalism," this strangely happened in socialist East Germany. But that is a different story, and Manjapra's research on the post-1945 period is too patchy to validate far-reaching conclusions. It is true that no living Indian ever again captured the German (and the global) imagination the way Tagore and Gandhi had done. At the same time, Indology and modern Indian studies have flourished in both German states, and all sorts of quests for "Eastern wisdom" continue to proliferate. Indian cultural theorists and historians, many of them expatriates working in the United States, are enjoying a prestige these days in German academia that would have been the envy of the interwar generation. Entanglement has turned global, and the up-to-date question seems to be: Where is Germany on Indian mental maps?

JÜRGEN OSTERHAMMEL

University of Konstanz, Germany 